\title{
Acceptance Speech
}

\section{Donald Ferencz}

Convenor of the Global Institute for the Prevention of Aggression

\author{
Magnifizenz, \\ Spectabilis, \\ Dear Elisabeth, \\ Dear guests of honour, \\ Dear Faculty and especially dear students!
}

As Claus has said before, we shall be hearing my father in a moment. Before we do that, I consider it a joyful privilege to be able to convey a few words of gratitude to all of you here today on behalf of my father. The following reply - though spoken by me - should be understood as coming directly from him.

Before conveying my thanks to all concerned for the very kind and prestigious award of an honorary doctorate from the University of Cologne, I should like to express my regret that I am not in a position to join you today. As some of you will know, I expect to very soon begin my $102^{\text {nd }}$ year, and I'm relying more these days on my son, Don, who is well-known to a number of you, to assist with such pleasant duties.

I should like to begin by offering my sincere greetings to the Rektor, to the Dean, and to the Faculty of the University of Cologne, including my friend Professor Claus Kreß, and to all the honoured guests, including my very dear friend, Elisabeth Kaul as well as the distinguished representatives of the International Nuremberg Principles Academy, with whom I've had the privilege of working over the years. I'd like to also recognize and to thank my son, Don, for his assistance on this special day and for working closely with Professor Kreß in helping to finalize the necessary details. It is with very fond remembrance that I recall the last time I was in Cologne, to honour our very dear and very dearly missed friend, Judge Hans-Peter Kaul. It gives me particular pleasure to know that Elisabeth Kaul is able to join us today.

We've been poignantly reminded this afternoon of an important transition - both for the University of Cologne itself and for Germany as a nation - from the very dark days of discrimination and persecution to 
considerably brighter days of leadership in advancing the rule of law. I am thankful that others may find inspiration in the lessons of my own life as to what can be accomplished in one very full lifetime. But as we all know, much work yet remains to be done, and perseverance will surely be a key ingredient in any future successes. This is why, as I've said many times, we must be prepared to never give up.

To receive an honorary degree from the hands of those responsible for training up the next generation of torch-bearers is deeply gratifying.

I thank you all and wish each of you the very best for the future. 


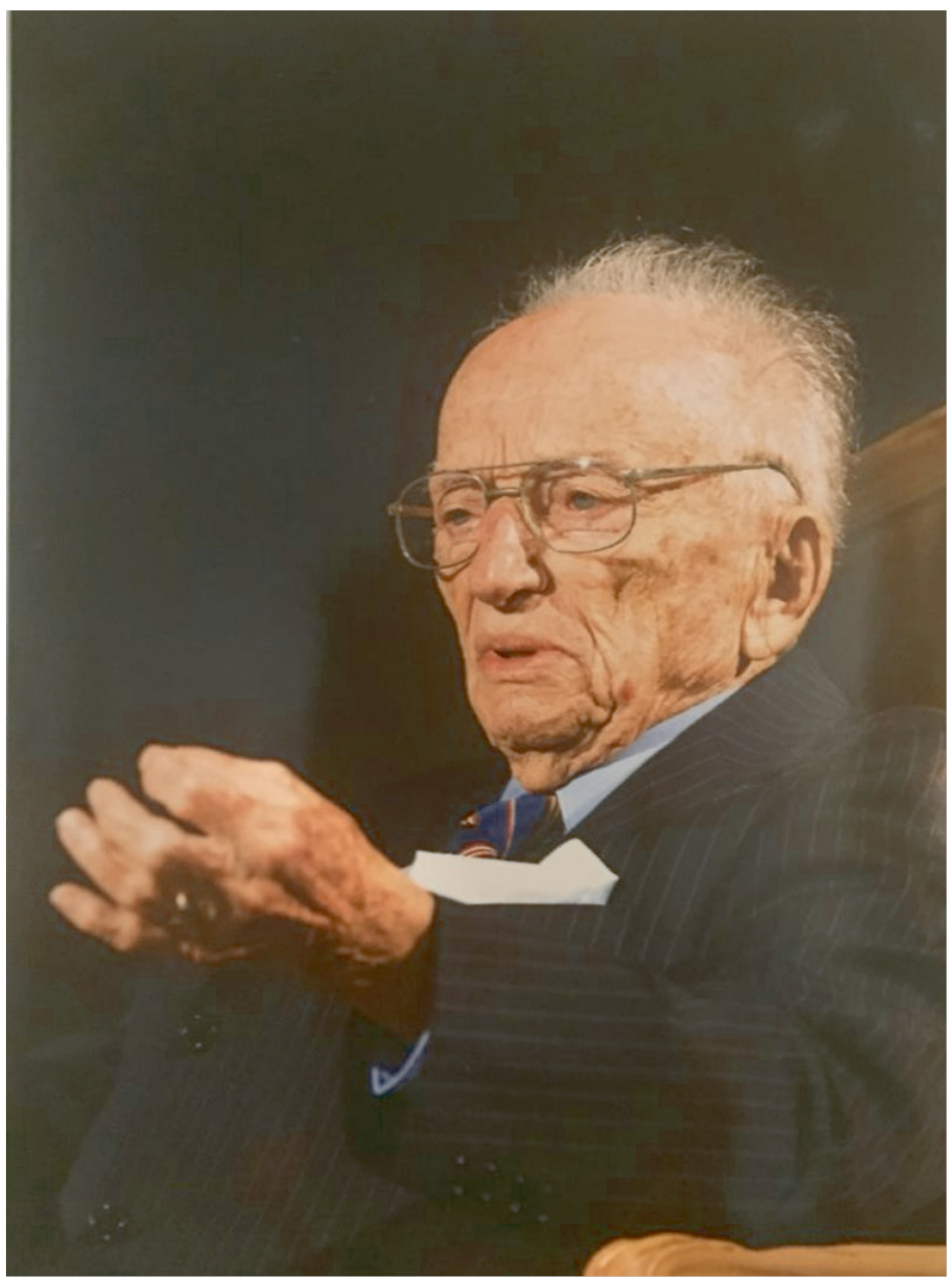


https://doi.org/10.5771/9783748913276-33

Generiert durch IP '172.22.53.54', am 26.04.2023, 14:29:48.

Das Erstellen und Weitergeben von Kopien dieses PDFs ist nicht zulässig. 